Jurnal Geografi, Edukasi dan Lingkungan (JGEL) Vol. 3, No. 2, Juli 2019:92-99

P-ISSN: 2579-8499; E-ISSN: 2579-8510

Doi: https://doi.org/10.29405/jgel.v3i2.3580

Website: http://journal.uhamka.ac.id/index.php/jgel

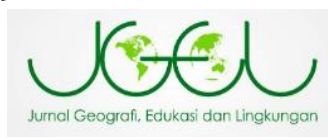

\title{
Prediksi Laju Erosi Menggunakan Metode USLE (Universal Soil Loss Equation) Di Desa Karang Tengah Kecamatan Babakan Madang Kabupaten Bogor
}

\author{
Rendika Dwi Hariyanto*, Tricahyono Nur Harsono, dan Fadiarman \\ Program Studi Pendidikan Geografi, FKIP Universitas Muhammadiyah Prof. DR. \\ Hamka, Jakarta Timur, Indonesia \\ *E-mail: rendika.bulak@gmail.com
}

Received: 22012019 / Accepted: 11042019 / Published online: 30072019

\begin{abstract}
ABSTRAK
Penelitian dilakukan di Desa Karang Tengah, Kecamatan Babakan Madang, Kabupaten Bogor yang memiliki morfologi beragam, mulai dari daerah dataran rendah sampai pegunungan dengan ketinggian mencapai 800 mdpl. Wilyah penelitian memiliki kelerengan dari miring sampai curam yang sangat berpotensi untuk terjadinya erosi, dan ditambah dengan adanya perubahan penggunaan lahan yang intensif dari area hijau ke pertanian. Untuk itu, tujuan penelitian untuk memprediksikan besarnya laju erosi di wilayah penelitian menggunakan Metode USLE. Jenis penelitian ini adalah penelitian survey dengan deskriptif. Populasi dalam penelitian ini adalah seluruh lahan di wilayah penelitian dengan sampel adalah lahan yang diambil berdasarkan data kemiringan lereng, penggunaan lahan, dan jenis tanah. Penetapan lokasi sampling menggunakan area sampling, sedangkan analisa hasil data menggunakan metode USLE (Universal Loss Soil Equation) yaitu memberi skor pada setiap parameter lahan, sehingga diperoleh klasifikasi bahaya erosi berdasarkan perhitungan menggunakan metode USLE. Hasil penelitian diketahui bahwa lahan di wilayah penelitian mempunyai klasifikasi bahaya erosi sangat ringan pada satuan lahan PLL meliputi wilayah Dusun Wangun bagian Utara, satuan lahan SLL meliputi wilayah Dusun Wangun bagian Timur, dan satuan lahan HLM di wilayah Dusun Wangun bagian Barat. Satuan lahan yang memiliki bahaya erosi ringan yaitu satuan lahan PkLL diwilayah Dusun Wangun bagian Selatan dan Dusun Tegalluhur bagian Utara, dan satuan lahan yang memiliki bahaya erosi sedang yaitu satuan lahan HLAm.
\end{abstract}

Kata Kunci: Prediksi Laju Erosi, Metode USLE

\begin{abstract}
This research did in Karang Tengah Village, Babakan Madang Distric, Bogor Regency that has variation morfologi condition from flat to mountain, with elevation at 800 meter. Research area has also slope condition from sloping to steep that potential occur erosion. In additional, there are landuse change significant happen from forest area to agriculture area. Based on that, the aims of research is to predict the magnitude of the rate of erosion in research area used the USLE Method. The type of research is descriptive survey. The population was all land in research area, and the sample was existing land based on slope, land use, and soil type. Determination of the sample location used the sampling area. The analysis of the data used the USLE method
\end{abstract}


(Universal Loss Soil Equation) that is scoring each land parameter. The erosion hazard classification is obtained based on calculations using the USLE method. The results showed that the land in research area has a very low erosion hazard occurend in the PLL land unit including Wangun Sub-Village in the North, SLL land unit including Wangun Sub-Village, and the HLM land unit in the Wangun Sub-Village in the West. While land units that have low erosion hazard are PkLL land units in the Southern part of Wangun Sub-Village, and North Tegalluhur Sub-Village. Land units that have moderate erosion hazard that is HLAm land units.

Keywords: Prediction of Erosion Rate, USLE Method

\section{PENDAHULUAN}

Sumberdaya alam utama yaitu tanah dan air pada dasarnya merupakan sumberdaya alam yang dapat diperbaharui, namun mudah mengalami kerusakan atau degradasi. Kerusakan tanah dapat terjadi oleh (1) kehilangan unsur tanah dan bahan organik di daerah perakaran, (2) terkumpulnya garam di daerah perakaran, (3) penjenuhan tanah oleh air, dan (4) erosi. Kerusakan tanah tersebut menyebabkan berkurangnya kemampuan tanah untuk mendukung pertumbuhan tanaman (Suripin, 2004).

Menurut Arsyad (2010), erosi adalah hilang atau terkikisnya tanah atau bagian-bagian tanah dari suatu tempat oleh air atau angin. Erosi menyebabkan hilangnya lapisan tanah yang subur dan baik untuk pertumbuhan tanaman serta berkurangnya kemampuan tanah untuk menyerap dan menahan air.

Pengangkutan erosi yang terjadi di daerah iklim basah pada umumnya adalah pengangkutan erosi oleh air (Arsyad, 2010). Menurut Sandy (1987) mengemukakan bahwa pengaruh iklim terhadap muka bumi serta segenap isinya, bukan saja besar, tetapi amat mendasar. Menurut pernyataan tersebut dapat diketahui bahwa berbagai variable yang mempengaruhi prediksi erosi berperan sangat penting dalam nilai erosi yang terjadi termasuk jenis tanah, vegetasi, dan panjang serta kemiringan lereng.

Hasil percobaan di Indonesia tahun 1930 di bebarapa jenis tanah menunjukkan dengan jelas perbedaan kepekaan erosi diberbagai tanah yang terbentuk. Coster (1983, dalam Arsyad 2010) dari penelitiannya di beberapa Pulau Jawa menunjukkan bahwa tanah Regosol dari bahan vulkan dan tanah Grumosol dari bahan induk mergel merupakan tanah yang sangat peka erosi, jika dibandingkan tanah Andosol atau Latosol yang terbentuk dari bahan volkan. Penelitian tersebut membenarkan adanya perbedaan erosi masing-masing jenis tanah.

Selain jenis tanah, vegetasi juga memegang peranan penting membentuk erosi. Erosi yang terjadi di hutan alam berbeda dengan erosi yang terjadi di hutan produksi. Menurut indeks vegetasi penutup tanah dan pengelolaan tanaman oleh Pusat Penelitian Tanah (dalam Arsyad 2010), hutan alam hanya menyumbang 0,005 nilai indeks erosi jika memiliki seresah sedikit, sedangkan hutan produksi menyumbang 0,5 nilai indeks erosi jika merupakan hutan produksi tebang habis. Nilai indeks 1 merupakan nilai indeks tertinggi. Begitu pula dengan vegetasi lainnya seperti jagung, padi, kedelai, kentang, dan lain-lain, masingmasing vegetasi memiliki perbedaan nilai indeks erosi.

Lereng yang terjal berpengaruh terhadap bersarnya jumlah aliran permukaan yang mengalir. Semakin curam lereng, semakin besar kecepatan aliran permukaan yang dengan demikian memperbesar energi angkut aliran 
permukaan (Arsyad 2010). Lereng dengan kemiringan 25-45\% memiliki indeks 6,8 dimana indeks 9,5 merupakan indeks yang menyatakan nilai terbesar. Panjang lereng berperan terhadap besarnya erosi yang terjadi, semakin panjang lereng maka semakin besar volume aliran permukaan yang terjadi. Kemiringan lereng memberikan pengaruh besar terhadap erosi yang terjadi, karena sangat mempengaruhi kecepatan limpasan permukaan. Makin besar nilai kemiringan lereng, maka kesempatan air untuk masuk kedalam tanah (infiltrasi) akan terhambat sehingga volume limpasan permukaan semakin besar yang mengakibatkan terjadinya bahaya erosi (Dewi, Trigunasih, \& Kusmawati, 2012).

Mengetahui besarnya erosi yang terjadi di suatu wilayah merupakan hal yang penting, karena selain dapat mengetahui banyaknya tanah yang terangkut juga dapat digunakan sebagai salah satu jalan untuk mencari sebuah solusi dari permasalahan tersebut. Prediksi erosi dapat dilakukan secara langsung maupun tidak langsung yaitu melalui model prediksi erosi. Prediksi erosi yang dilakukan secara langsung menemui banyak kendala, salah satunya adalah waktu yang dibutuhkan untuk mengerjakan cukup lama, sehingga digunakan sebuah model prediksi erosi, model prediksi erosi itu sendiri cukup beragam, seperti halnya USLE (Universal Soil Loss Equation), ANSWER (Areal Nonpoint Source Watershed Environment Respon Simulation), GUEST (Griffith University Erosion System Template) dan masih banyak lagi model prediksi lainnya.

Kegiatan penelitian pengendalian erosi meliputi: (1) pengembangan model (metode) prediksi erosi, dan (2) penelitian untuk mencari dan/atau mengkaji teknik pengendalian erosi. Metode (model) prediksi yang paling banyak dikembangkan dan diaplikasikan di Indonesia adalah USLE (Universal Soil
Loss Equation) untuk mendapatkan nilai faktor-faktor (R) erosivitas hujan, (K) erodibilitas tanah, panjang dan kemiringan lereng (LS) (C) vegetasi dan pengelolaan tanaman, dan $(\mathrm{P})$ konservasi tanah. Metode USLE sering digunakan untuk memprediksi tingkat bahaya erosi dan perencanaan penggunaan lahan, serta pemilihan alternatif teknik konservasi tanah.

Kondisi morfologi wilayah penelitian angat beragam mulai dari daerah dataran rendah sampai pegunungan dengan ketinggian mencapai 800 mdpl. Kemiringan lereng dari miring sampai curam yang sangat berpotensi untuk terjadinya erosi, dan ditambah adanya perubahan penggunaan lahan yang intensif dari lahan hijau ke pertanian. Vegetasi tanaman yang ada di wilayah penelitian sudah berkurang banyak, pohon berjenis pinus dan cemara yang mampu menyerap air sudah banyak berganti dengan sawah dan tanaman singkong. Oleh karena itu, untuk mengetahui prediksi erosi di wilayah penelitian penting, hal ini terkait dengan semakin banyaknya tanah yang mengalami kerusakan.

\section{METODE PENELITIAN \\ Waktu dan Lokasi Penelitian}

Penelitian ini dilakukan pada bulan Mei 2018 sampai dengan Juli 2018. Lokasi penelitian di Desa Karang Tengah Kecamatan Babakan Madang, Kabupaten Bogor (Gambar 1), karena memiliki kemiringan lereng yang bervariasi dari miring sampai curam, dan adanya perubahan penggunaan lahan yang intensif, sehingga kondisi ini memperbesar kemungkinan erosi yang intensif.

\section{Populasi dan Sampel}

Populasi dalam penelitian ini adalah seluruh lahan di Desa Karang Tengah Kecamatan Babakan Madang 
Kabupaten Bogor. Sampel dalam penelitian ini adalah sebagian lahan di wilayah penelitian dengan pengambilan sampel menggunakan metode area sampling berdasarkan pada satuan lahan. Penentuan satuan lahan dilakukan dengan overlay antara peta tanah, peta kemiringan lereng, dan peta penggunaan lahan yang setiap peta mempunyai skala 1:75.000.

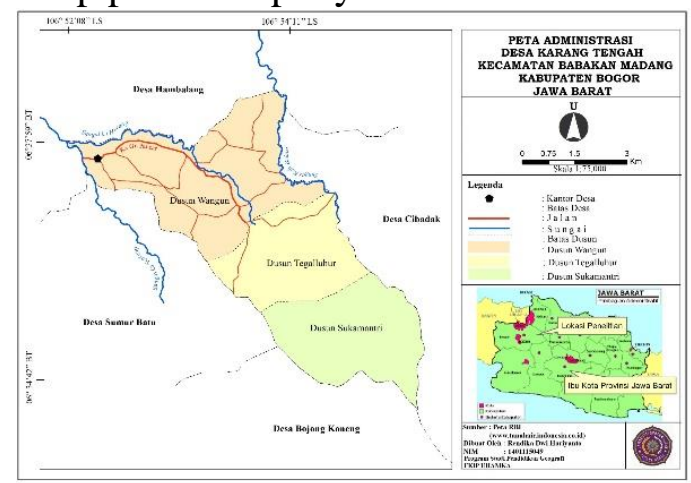

Gambar 1. Peta Lokasi Penelitian

Berdasarkan hasil overlay diketahui bahwa lahan di wilayah penelitian menjadi lima satuan lahan yaitu : PLL (Permukiman Asosiasi Latosol Coklat Landai) meliputi wilayah Dusun Wangun bagian Utara, PkLL (Perkebunan Asosiasi Latosol Coklat) diwilayah Dusun Wangun bagian Selatan dan Dusun Tegalluhur bagian Utara, SLL (Sawah Asosiasi Latosol Coklat) meliputi wilayah Dusun Wangun bagian Timur, HLAm (Hutan Asosiasi Latosol Coklat Agak Miring) diwilayah Dusun Sukamantri Dusun Tegalluhur bagian Selatan, HLM (Hutan Asosiasi Latosol Coklat Miring) diwilayah Dusun Wangun (Gambar 2).

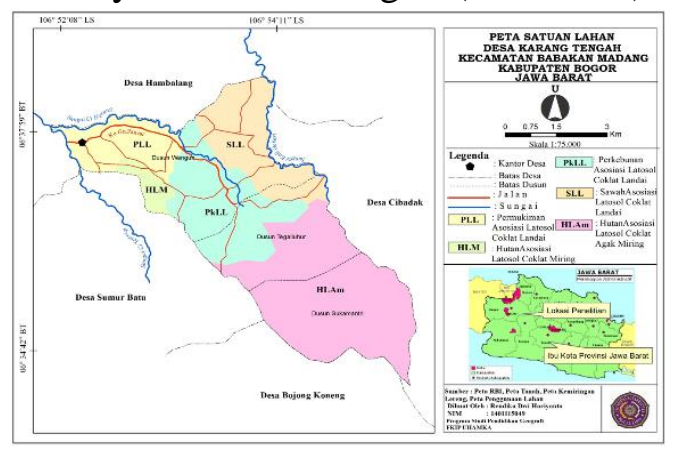

Gambar 2. Peta Satuan Lahan Wilayah Penelitian

\section{Jenis Penelitian}

Penelitian ini adalah penelitian survey dengan metode deskriptif, menurut Singarimbum dan Effendi (1987), penelitian survey adalah penelitian yang mengambil sampel dari suatu populasi menggunakan kuesioner sebagai alat pengumpulan data yang pokok. Pabundu Tika (2005), mengemukakan bahwa penelitian survey merupakan metode penelitian yang bertujuan untuk mengumpulkan sejumlah besar dara berupa variable, unit atau individu dalam waktu bersamaan. Penelitian ini merupakan penelitian survey karena peneliti mengumpulkan data terkait panjang lereng, pengelolaan tanaman dan vegetasi penutup untuk identifikasi laju erosi.

\section{Metode Pengumpulan, Pengolahan, dan Analisis Data}

Data primer yang dalam penelitian ini adalah data panjang lereng (L), data pengelolaan tanaman dan vegetasi penutup (C), dan data tindakan khusus konservasi tanah $(\mathrm{P})$. Data sekunder dari penelitian ini yaitu data erosivitas (R) meliputi curah hujan, data erodibilitas tanah (K), data kemiringan lereng (S). Analisis data diawali dengan pembagian satuan lahan dengan teknik overlay sehingga diperoleh satuan-satuan lahan. Pada masing-masing satuan lahan dilakukan pengambilan data berdasarkan metode USLE (Universal Soil Loss Equation) yaitu erosivitas (R), erodibilitas tanah (K), panjang lereng (L), kemiringan lereng (S), vegetasi dan pengelolaan tanaman $(\mathrm{C})$, dan tindakan konservasi $(\mathrm{P})$. yang di jumlah dengan rumus $(\mathrm{A}=$ R.K.L.S.C.P). Hasil analisis menggunakan metode USLE didapatkan prediksi erosi ditiap satuan lahan dengan satuan (ton/ha/tahun). Klasifikasi tingkat erosi wilayah penelitian mengacu pada klasifikasi menurut Kirionto 2013 yang disajikan pada Tabel 1. 
Tabel 1. Klasifikasi Bahaya Erosi

\begin{tabular}{|c|c|c|}
\hline $\begin{array}{c}\text { Kelas } \\
\text { Bahaya } \\
\text { Erosi }\end{array}$ & $\begin{array}{c}\text { Laju Erosi } \\
\text { (ton/ha/tahun) }\end{array}$ & Keterangan \\
\hline I & $<15$ & Sangat ringan \\
\hline II & $15-60$ & Ringan \\
\hline III & $60-180$ & Sedang \\
\hline IV & $180-480$ & Berat \\
\hline V & $>480$ & Sangat berat \\
\hline
\end{tabular}

Sumber: Kironoto, 2003 (dalam I Gede

Tunas, 2005)

\section{HASIL DAN PEMBAHASAN \\ 1. Deskripsi Prediksi Erosi}

a. Erosivitas (R)

Data curah hujan yang digunakan dalam penelitian ini merupakan data hujan hasil pengukuran curah hujan Stasiun Stasiun BMKG (Badan Meteorologi Klimatologi dan Geofisika) Citeko, Cisarua-Jawa Barat. Data suhu udara di daerah penelitian yang digunaka selama 5 tahun (2013-2017) yang memiliki jarak terdekat $\pm 16 \mathrm{~km}$. Selanjutnya dihitung menggunakan rumus Lenvain (1989, dalam Qurratul Ayunin, 2008):

$\mathrm{IR}=2,21 \mathrm{P}^{1,36}$

$\mathrm{IR}=$ Indeks Erosivitas

$\mathrm{P}=$ Curah Hujan Bulanan $(\mathrm{cm})$

Hasil perrhitungan nilai erosivitas disajikan pada Tabel 2.

Tabel 2. Indeks Erosivitas Hujan di Desa Karang Tengah

\begin{tabular}{|l|c|c|c|}
\hline Bulan & $\begin{array}{c}\text { Rata- } \\
\text { rata } \\
\text { curah } \\
\text { hujan } \\
\text { Bulanan } \\
\text { (P mm) }\end{array}$ & $\begin{array}{c}\text { Curah } \\
\text { Hujan } \\
\text { Bulanan } \\
(\mathbf{c m})\end{array}$ & $\begin{array}{c}\text { Indeks } \\
\text { Erosivitas } \\
\text { (IR) }\end{array}$ \\
\hline Januari & 297,4 & 29,7 & 222,91 \\
\hline Februari & 285,1 & 28,5 & 210,46 \\
\hline Maret & 272,6 & 27,2 & 198,01 \\
\hline April & 193,7 & 19,3 & 124,41 \\
\hline Mei & 174,9 & 17,4 & 108,28 \\
\hline Juni & 111,3 & 11,1 & 58,56 \\
\hline Juli & 73,1 & 7,3 & 33,06 \\
\hline Agustus & 98,3 & 9,8 & 49,46 \\
\hline
\end{tabular}

\begin{tabular}{|l|c|c|c|}
\hline September & 179,1 & 17,9 & 111,84 \\
\hline Oktober & 248 & 24,8 & 174,11 \\
\hline November & 268,5 & 26,8 & 193,97 \\
\hline Desember & 237,4 & 23,7 & 164,07 \\
\hline Jumlah & $\mathbf{2 4 4 5 , 4}$ & $\mathbf{2 4 4 , 5}$ & $\mathbf{1 6 4 9 , 1 4}$ \\
\hline
\end{tabular}

b. Erodibilitas (K)

Hasil pengamatan Peta Sumber Daya Tanah Tingkat Tinjau Lembar DKI Jakarta dan Jawa Barat, dan berdasarkan tabel acuan menunjukkan bahwa di wilayah penelitian terdapat jenis tanah yaitu Asosiasi Latosol Coklat yang masing masing memiliki Nilai $\mathrm{K}$ yaitu 0,091. Apabila nilai erodibilitas tanah tinggi maka tanah peka atau mudah tererosi, dan sebaliknya apabila erodibilitas tanahnya rendah maka tanah lebih tahan terhadap erosi.

\section{c. Faktor Lereng (LS)}

Klasifikasi kemiringan lereng dan analisis faktor lereng (LS) di wilayah penelitian di sajikan pada Tabel 3 .

Tabel 3. Klasifikasi dan Nilai LS Tiap Satuan Lahan di Desa Karang Tengah

\begin{tabular}{|c|c|c|c|}
\hline $\begin{array}{c}\text { Satuan } \\
\text { Lahan }\end{array}$ & $\begin{array}{c}\text { Kemiringan } \\
(\%)\end{array}$ & $\begin{array}{c}\text { Klasifikasi } \\
\text { Lereng }\end{array}$ & $\begin{array}{c}\text { Nilai } \\
\text { LS }\end{array}$ \\
\hline $\begin{array}{c}\text { PLL, } \\
\text { SLL, } \\
\text { PkLL }\end{array}$ & 4,6 & $\begin{array}{c}\text { Landai/Bero } \\
\text { mbak }\end{array}$ & 0,4 \\
\hline HLAm & 10,2 & $\begin{array}{c}\text { Agak } \\
\text { Miring/Berge } \\
\text { lombang }\end{array}$ & 1,4 \\
\hline HLM & 25 & $\begin{array}{c}\text { Miring/Berbu } \\
\text { kit }\end{array}$ & 3,1 \\
\hline
\end{tabular}

d. Perhitungan Indeks Faktor Penutup Lahan (C)

Vegetasi tanah dan pengelolaan tanaman di wilayah penelitian beragam, seperti tanaman padi, kebun campuran yang berada di dataran yang lebih rendah. Pada wilayah ke arah Gunung Pancar mulai ditemukan tanaman-tanaman seperti ubi, hutan dengan sedikit serasah. Nilai $\mathrm{C}$ dan sebaran jenis tanaman di Indonesia di sajikan pada Tabel 4. 
Tabel 4. Tabel Penilaian Vegetasi Penutup Tanah dan Pengelolaan Tanaman

\begin{tabular}{|c|c|c|}
\hline $\begin{array}{c}\text { Satuan } \\
\text { Lahan }\end{array}$ & Jenis Vegetasi & Nilai C \\
\hline PLL & Belukar/Rumput & 0,3 \\
\hline PkLL & Ubi & 0,8 \\
\hline SLL & Sawah & 0,05 \\
\hline HLAm & Pisang & 0,6 \\
\hline HLM & $\begin{array}{c}\text { Hutan Alam } \\
\text { Sedikit Seresah }\end{array}$ & 0,002 \\
\hline
\end{tabular}

\section{e. Tindakan Konservasi (P)}

Tindakan Konservasi tanah di wilayah peneltiian terdapat 3 jenis yaitu teras bangku di satuan lahan SLL dan PLL, penanaman/pengolahan menurut kontur pada lereng $10,2 \%$ pada satuan lahan HLAm dan lereng $25 \%$ pada satuan lahan HLM, serta Penanaman tanaman penutup tanah rendah pada tanaman perkebunan (kerapatan sedang) pada satuan lahan PkLL. Nilai tindakan konservasi $(\mathrm{P})$ dapat (Tabel 5).

Tabel 5. Tindakan Konservasi Tanah di Desa Karang Tengah

\begin{tabular}{|c|l|c|}
\hline $\begin{array}{c}\text { Satuan } \\
\text { Lahan }\end{array}$ & Tindakan Konservasi & NIlai P \\
\hline PLL & $\begin{array}{l}\text { Teras Bangku (Standar } \\
\text { desain dan bangunan } \\
\text { sedang) }\end{array}$ & 0,15 \\
\hline PkLL & $\begin{array}{l}\text { Penanaman tanaman } \\
\text { penutup tanah rendah } \\
\text { pada tanaman } \\
\text { perkebunan } \\
\text { (kerapatan sedang) }\end{array}$ & 0,5 \\
\hline SLL & $\begin{array}{l}\text { Teras Bangku (Standar } \\
\text { desain dan bangunan } \\
\text { baik) }\end{array}$ & 0,04 \\
\hline HLAm & $\begin{array}{l}\text { Penanaman/pengolaha } \\
\text { n menurut kontur pada } \\
\text { lereng 10,2\% }\end{array}$ & 0,75 \\
\hline HLM & $\begin{array}{l}\text { Penanaman/pengolaha } \\
\text { n menurut kontur pada } \\
\text { lereng (25\%) }\end{array}$ & 0,90 \\
\hline
\end{tabular}

\section{Prediksi Erosi Menggunakan Metode USLE (Universal Soil Loss Equation)}

Berdasarkan persamaan USLE (Universal Soil Loss Equation), faktor- faktor erosi yang akan dihitung meliputi faktor erosivitas hujan (R), faktor erodibilitas (K), faktor panjang dan kemiringan lereng (LS), dan faktor pengelolaan tanaman dan usaha pencegahan erosi (CP). Prediksi besarnya laju erosi pada masing-masing lahan yang didapatkan digunakan untuk menentukan klasifikasi bahaya erosi. Hasil prediksi besarnya laju erosi di wilayah penelitian disajikan pada tabel 6 .

Tabel 6. Prediksi Laju Erosi di wilayah penelitian Menggunakan Metode USLE

\begin{tabular}{|c|c|c|c|c|c|}
\hline \multirow[b]{2}{*}{$\begin{array}{c}\text { Indeks } \\
\text { Penilaian }\end{array}$} & \multicolumn{5}{|c|}{ Satuan Lahan } \\
\hline & PLL & $\begin{array}{c}\text { PkL } \\
\text { L }\end{array}$ & SLL & $\begin{array}{c}\text { HLA } \\
\text { m }\end{array}$ & $\begin{array}{c}\text { HL } \\
\mathbf{M}\end{array}$ \\
\hline Erosivitas & 1649 & 1649 & 1649 & 1649,1 & 1649 \\
\hline Hujan (R) &, 14 &, 14 &, 14 & 4 &, 14 \\
\hline $\begin{array}{l}\text { Erodibilit } \\
\text { as Tanah } \\
\text { (K) }\end{array}$ & $\begin{array}{c}0,09 \\
1\end{array}$ & $\begin{array}{c}0,09 \\
1\end{array}$ & $\begin{array}{c}0,09 \\
1\end{array}$ & 0,091 & $\begin{array}{c}0,09 \\
1\end{array}$ \\
\hline $\begin{array}{l}\text { Faktor } \\
\text { Lereng } \\
\text { (LS) }\end{array}$ & 0,4 & 0,4 & 0,4 & 1,4 & 3,1 \\
\hline $\begin{array}{l}\text { Vegetasi } \\
\text { Penutup } \\
\text { Tanah/Pe } \\
\text { ngolahan } \\
\text { Tanaman } \\
\text { (C) }\end{array}$ & 0,3 & 0,8 & 0,05 & 0,6 & $\begin{array}{c}0,00 \\
2\end{array}$ \\
\hline $\begin{array}{l}\text { Tindakan } \\
\text { Konserva } \\
\text { si (P) }\end{array}$ & 0,15 & 0,5 & 0,4 & 0,75 & 0,90 \\
\hline $\begin{array}{l}\text { Besar } \\
\text { Laju } \\
\text { Erosi (A) } \\
\text { (ton/ha/ta } \\
\text { hun) }\end{array}$ & 2,70 & $\begin{array}{c}24,0 \\
1\end{array}$ & 1,20 & 94,54 & $\mathbf{0 , 8 3}$ \\
\hline
\end{tabular}

Berdasarkan prediksi bersarnya laju erosi di wilayah penelitian pada masing-masing satuan lahan, selanjutnya dilakukan penentuan klasifikasi bahaya erosi berdasarkan klasifikasi bahaya erosi. Hasil klasifikasi bahaya erosi di wilayah penelitian disajikan pada tabel 7. Prediksi besarnya laju erosi terkecil terjadi pada satuan lahan HLM (Hutan Asosiasi Latosol Coklat Miring) yaitu 0,83 ton/ha/tahun. Besarnya laju erosi terbesar terjadi pada satuan lahan HLAm (Hutan 
Asosiasi Latosol Coklat Agak Miring) yaitu 94,54 ton/ha/tahun.

Tabel 7. Klasifikasi Bahaya Erosi di Desa Karang Tengah

\begin{tabular}{|c|c|c|c|}
\hline $\begin{array}{c}\text { Satuan } \\
\text { Lahan }\end{array}$ & $\begin{array}{c}\text { Laju Erosi } \\
\text { (ton/ha/tah } \\
\text { un) }\end{array}$ & $\begin{array}{c}\text { Interval } \\
\text { Klasifikasi } \\
\text { Laju Erosi } \\
\text { (ton/ha/tahu } \\
\text { n) }\end{array}$ & $\begin{array}{c}\text { Keterang } \\
\text { an }\end{array}$ \\
\hline PLL & 2,70 & $<15$ & $\begin{array}{c}\text { Sangat } \\
\text { ringan }\end{array}$ \\
\hline PkLL & 24,01 & $15-60$ & Ringan \\
\hline SLL & 1,20 & $<15$ & $\begin{array}{c}\text { Sangat } \\
\text { ringan }\end{array}$ \\
\hline HLAm & 94,54 & $60-180$ & Sedang \\
\hline HLM & 0,83 & $<15$ & $\begin{array}{c}\text { Sangat } \\
\text { ringan }\end{array}$ \\
\hline
\end{tabular}

Berdasarkan hasil analisis prediksi besarnya laju erosi pada tabel 7 dapat diketahui bahwa di wilayah peneltiian terdapat tiga klasifikasi bahaya erosi yaitu, sangat ringan, ringan, dan sedang. Peta bahaya erosi di wilayah penelitian disajikan pada Gambar 3.

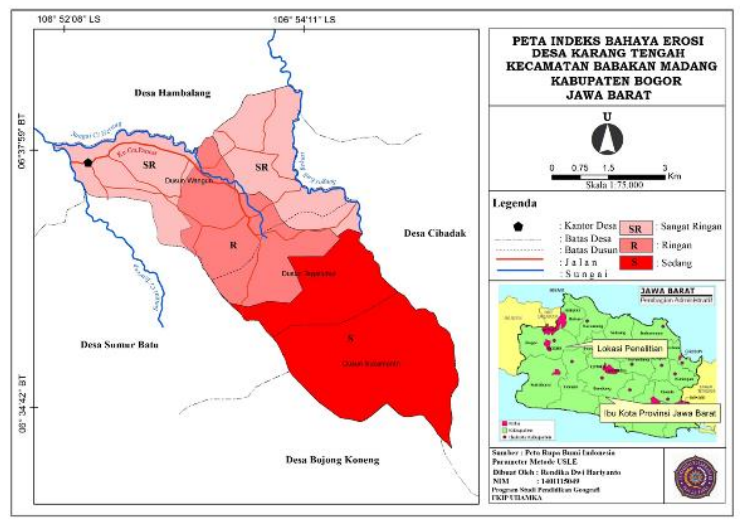

Gambar 3. Peta Bahaya Erosi

\section{KESIMPULAN}

Berdasarkan hasil penelitian menunjukkan bahwa prediksi besarnya laju erosi di wilayah penelitian berkisar antara 0,83 ton/ha/tahun sampai dengan 94,54 ton/ha/tahun. Laju erosi ini tergolong pada klasifikasi besarnya laju erosi sangat ringan sampai sedang. Laju erosi terbesar yaitu 94,54 ton/ha/tahun (sedang) terjadi pada satuan lahan HLAm (Hutan Asosiasi Latosol Coklat Agak Miring) yang meliputi wilayah Dusun Sukamantri dan Dusun Tegalluhur bagian Selatan. Adapun besarnya laju erosi terkecil yaitu 0,83 ton/ha/tahun (sangat ringan) terjadi pada satuan lahan HLM (Hutan Asosiasi Latosol Coklat Miring) yang meliputi wilayah Dusun Wangun. Selain itu, besarnya laju erosi 1,2 ton/ha/tahun (sangat ringan) terjadi pada satuan lahan SLL (Sawah Asosiasi Latosol Coklat Landai) meliputi wilayah Dusun Wangun bagian Timur, dan besarnya laju erosi sebesar 2,71 ton/ha/tahun (sangat ringan) terjadi pada satuan lahan PLL (Permukiman Asosiasi Latosol Coklat Landai) yang meliputi wilayah Dusun Wangun bagian Utara. Laju erosi sebesar 24,01 ton/ha/tahun (ringan) terjadi pada satuan lahan PkLL (Perkebunan Asosiasi Latosol Coklat Landai) yang meliputi wilayah Dusun Wangun bagian Selatan dan Dusun Tegalluhur bagian Utara.

\section{DAFTAR PUSTAKA}

Dewi, I. G. A. S. U., Trigunasih, N. M., \& Kusmawati, T. (2012). Prediksi Erosi dan Perencanaan Konservasi Tanah dan Air pada Daerah Aliran Sungai Saba. E-Jurnal Agroekoteknologi Tropika, 1(1), 12-23.

Hefni Efendi. (2003). Telaah Kualitas Air Bagi Pengelolaan Sumber Daya dan Lingkungan Perairan. Yogyakarta : Kanisius.

I Gede Tunas (2005). Prediksi Erosi Lahan DAS Bengkulu dengan Sistem Informasi Geografis (SIG). SMARTek, 3(3), 137145. 
99 | Jurnal Geografi, Edukasi dan Lingkungan (JGEL) Vol. 3, No. 2, Juli 2019: $92-99$

Moh. Pabundu Tika (2005). Metodologi Penelitian Geografi. Jakarta : PT. Bumi Aksara.

Sitnala, Arsyad. (2012). Penyelamatan Tanah, Air, dan Lingkungan. Jakarta : CrestPrent dan Yayasan Pustaka Obor Indonesia.

Sitnala, Arsyad. (2010). Konservasi

Tanah dan Air. Bogor : IPB Press.

Suripin (2004). Pelestarian Sumber Daya Tanah dan Air. Yogyakarta : Andi. 